\title{
Increase in Serum Total IGF-I and Maintenance of Free IGF-I Following Intentional Weight Loss in Pre-menopausal Women at Increased Risk of Breast Cancer
}

\author{
Harvie M. ${ }^{*}{ }^{1}$, Renehan A.G. ${ }^{2}$, Frystyk J. ${ }^{3}$, Flyvbjerg A. ${ }^{3}$, Mercer T. ${ }^{4}$, Malik R. ${ }^{5}$, Adams J. ${ }^{5}$, \\ Cuzick J. ${ }^{6}$ and Howell A. ${ }^{1}$ \\ ${ }^{I}$ Genesis Prevention Centre, University Hospital of South Manchester NHS Foundation Trust, Manchester, UK \\ ${ }^{2}$ School of Cancer, Enabling Sciences and Technology, University of Manchester, UK \\ ${ }^{3}$ The Medical Research Laboratories, Clinical Institute, Aarhus University Hospital, Aarhus, Denmark \\ ${ }^{4}$ Department of Physiotherapy, Queen Margaret University, Edinburgh, UK \\ ${ }^{5}$ Department of Clinical Radiology, University of Manchester, UK \\ ${ }^{6}$ Cancer Research UK Departments of Epidemiology, Mathematics and Statistics, Wolfson Institute of Preventive \\ Medicine London, UK
}

\begin{abstract}
Intentional weight loss may reduce breast cancer risk through lowering levels of circulating free IGF-I but few studies have measured this longitudinally. We determined the effect of weight loss ( $\geq 5 \%$ body weight) over 12 months, using an energy restriction and exercise programme, on an expanded panel of IGF-related peptides amongst 23 weight losing and 46 weight stable or gaining pre-menopausal women at increased risk of breast cancer, BMI (mean \pm SD) $29.2 \pm$ $6.2 \mathrm{~kg} / \mathrm{m}^{2}$. Fasting measures of total and free IGF-I (ultra-filtration), and IGFBP-1, -2 and -3 , body weight, body fat (DXA), intra-abdominal fat (MRI) were assessed at 6 and 12 months.

After 12 months, women who lost $\geq 5 \%$ of body weight had a significant increase in serum total IGF-I; mean (95\% CI difference) 17 (2.3 to 34.0) $\mu \mathrm{g} / 1, \mathrm{P}<0.05$, and IGFBP-2; mean (95\% CI ratio) 1.24 (1.06 to 1.46 ) $\mathrm{P}<0.001$, compared to weight stable/gaining women. Serum IGFBP-1 tended to increase in weight losers compared to the weight stable/gaining women; mean (95\% CI ratio) 1.19 (0.97 to 1.45$) \mathrm{P}=0.09$, whereas IGFBP-3 remained unchanged; mean (95\% CI ratio) 1.02 (0.94 to 1.20$] \mathrm{P}=0.99$. Weight loss did not significantly alter serum levels of free IGF-I; mean difference $0.1(-0.1$ to 3.4) $\mu \mathrm{g} / 1, \mathrm{P}=0.21$.

Increased serum total IGF-I levels, and maintenance of free IGF-I despite increased concentrations of serum IGFBP-1 and -2 with weight loss, does not suggest intentional weight loss with diet and exercise mediates reduced risk through the circulating IGF-axis.
\end{abstract}

Keywords: Intentional weight loss, IGF-I, free IGF-I, IGFBP-1, IGFBP-2, breast cancer.

\section{INTRODUCTION}

Observational prospective studies consistently link excess body weight [1] and weight gain in the pre- or postmenopausal periods with the subsequent development of post-menopausal breast cancer [2]. Within cohort studies with retrospectively collected adult life weight changes, we [3] and others [4] have shown that a pre- or post-menopausal weight loss of $\geq 5 \%$ reduces risk of postmenopausal breast

*Address correspondence to this author at the Genesis Prevention Centre, University Hospital of South Manchester NHS Foundation Trust, Manchester, M23 9LT, UK; Tel: +44 (0) 161291 4410; Fax: +44 (0) 161 291 4412; E-mail: michelle.harvie@manchester.ac.uk cancer. The biological mechanism of risk reduction following intentional weight loss is unclear, but may be linked with the IGF-axis [5]. Total IGF-I levels have been linked to risk of both pre- [6] and more recently post-menopausal breast cancer [7]. The IGF-I axis is nutritionally regulated. Specifically, circulating levels of free IGF-I, considered by many as a surrogate of tissue bio-availability, are dependent upon circulating concentrations of IGF-binding proteins (IGFBPs), chiefly IGFBP-3, with IGFBP-1 and -2 as the main acute regulators [8]. Weight loss may improve insulin sensitivity and thereby increase serum levels of IGFBP-1 and -2 [9-11], which in turn may reduce total levels of free IGF-I. This is supported by some [5] but not all cross-sectional data [12] but few studies have measured this relationship in a longitudinal setting. 
We have tested the hypothesis that intentional weight loss increases serum concentrations of IGFBPs while reducing levels of free IGF-I and/or total IGF-I, as biomarkers of breast cancer risk. This study determined changes in an expanded panel of IGF-related peptides and insulin sensitivity in pre-menopausal women at increased risk of breast cancer, during a 6 month weight loss period followed by a 6 month weight maintenance period. To distinguish potential effects on the IGF axis due to differential changes in different adipose body compartments, we also determined total body fat using dual energy X-ray absorptiometry (DXA] and intra-abdominal fat (IAF] using magnetic resonance imaging (MRI).

\section{MATERIALS AND METHODOLOGY}

\section{Participants}

We studied 74 pre-menopausal women aged 35-45 years with a family history of breast cancer (Tyrer Cuzick Model [13] estimated lifetime risk of 1 in 3 to 1 in 6) and relatively large adult weight gain $(>7 \mathrm{~kg})$ since aged 20 years. Participants were sedentary, non-smokers, not currently dieting or losing weight, had regular menstrual cycles and no evidence of hyperandrogenism or polycystic ovary syndrome (PCOS] [14]. They had not taken oral contraceptives during the previous 6 months, were not currently on a high phytoestrogen diet and had alcohol intakes of less than 28 units/week. They did not have diabetes, cardiovascular disease or previous history of cancer. Recruitment was by mailing all eligible women attending a Regional Breast Cancer Family History Clinic. Volunteers were assigned either to a 12 month energy restricted and exercise weight loss intervention group $(n=40)$ or a control group $(n=34)$. Study group allocation was based on the proximity of the participants to the hospital and ability to attend the hospitalbased weight loss and exercise programme.

We performed comparative analyses based on an intervention-response basis (rather than intention-to-treat). Several women in the weight loss arm did not lose weight (n $=6)$ and several in the control arm did lose weight $(n=6)$. For this reason we ignored the allocation groups for analysis and instead identified two groups based on their weight outcome: firstly women losing $\geq 5 \%$ body weight in the first 6 months, the "weight loss group" (WLG), and secondly women who were weight stable or gained weight during the first six months, the "weight stable or weight gain group" (WSWGG). This study was approved by South Manchester Hospitals Ethics Committee (Reference no 01/426).

\section{Weight Loss Intervention}

The weight loss/exercise group were advised to follow an energy restricted diet providing $1680-3780 \mathrm{~kJ}$ below their estimated energy requirements (1.4 times x estimated resting energy expenditure) [15] based on $20 \%$ energy from protein, $30 \%$ from fat and $50 \%$ from carbohydrate. They were also instructed to increase exercise gradually to include five 30 minute sessions of moderate exercise (defined as $50-60 \%$ of maximal heart rate) each week [16]. The intervention was designed to achieve a gradual weight loss of $0.5-1 \mathrm{~kg} /$ week and lead to a weight loss of $5 \%$ or greater at 6 months and maintenance of this weight loss at 12 months. Participants in the control group were given general lifestyle advice to reduce risk of cancer; lose weight, increase exercise, increase intake of fruit and vegetables and moderate intake of alcohol, fat and meat [17]. Adherence to diet advice was assessed using 4-day food diaries analysed using Compeat 4 Nutrition Analysis System (Carlson Bengston Consultants, London, UK), and to exercise advice using a 7 day physical activity recall [18] and the 6 minute walk test as a measure of fitness [19] at baseline, 6 and 12 months.

\section{Weight-Related Outcome Measures}

At baseline, 6 and 12 months we measured weight, height, waist and hip circumferences using standardised methods [20]. Total body fat was measured using a DXA whole body Hologic QDR 4500A scanner and V8.26a:3 software (Hologic Inc., Bedford, MA, USA) (coefficient of variation $[\mathrm{CV}]$ : fat mass $1.8 \%$, lean muscle mass $0.6 \%$ ). IAF was measured using MRI with a single axial water suppressed image at the L2/L3 vertebra level, with the technician blinded to the group allocation. Overall standardised CV of IAF estimation was $7.3 \%$.

\section{Serum IGF and Insulin Assays}

A 12 hour fasted morning blood sample was collected at baseline, 6 and 12 months. Serum was aliquoted, stored at $70^{\circ} \mathrm{C}$ and batched so that all samples from a participant were included in the same assay. Laboratory personnel were blinded to the sample identity. Samples were not collected on a specific day of the menstrual cycle; however day of cycle was recorded and adjusted for in the analyses [21]. Most laboratory measurements of IGF-I and binding proteins IGFBP-1 and -2 were performed in the Medical Research Laboratories at Aarhus University Hospital, Denmark. Total IGF-I was measured by an in-house non-competitive time resolved immunofluorometric assay (TR-IFMA) [22] and free IGF-I was measured using ultra-filtration by centrifugation [23]. IGFBP-1 and IGFBP-2 were determined using an in-house radioimmunoassay (RIA) and TR-IFMA respectively, as previously described [24]. Remaining assays were conducted at the Biochemistry Department South Manchester Hospitals: IGFBP-3 by immunoradiometric assay (IRMA) (Diagnostic Systems Laboratories, TX, USA); glucose by the hexokinase/glucose-6-phosphate dehydrogenase method (Bayer Newbury, England); and insulin by electrochemiluminescence immunoassay (Elecsys Roche Diagnostics, Lewes, England). Fasting insulin and glucose were combined to calculate the insulin sensitivity index using the homeostasis model assessment (HOMA) [25]. The molar ratio of IGF-I:IGFBP-3 was calculated as a proxy of free IGF-I [26]. The intra-assay CVs were as follows: insulin $0.7 \%$; total IGF-I 3.2\%; free IGF-I $12.0 \%$; IGFBP-1 $5.3 \%$; IGFBP-2 5.0\%; and IGFBP-3 4.2\%.

\section{Statistical Analysis}

Data were analysed using SPSS (version 14, SPSS Ltd, Chicago, IL, USA). Statistical significance was accepted at $\mathrm{P}<0.05$. We compared changes in the IGF-I axis between 
women losing $\geq 5 \%$ body weight in the first 6 months (WLG), and women who were weight stable or gained weight during the first six months (WSWGG). We performed analyses of variance (ANOVA) adjusted for baseline levels of each parameter and factors potentially related to the IGF-I axis: day of menstrual cycle, dietary energy and protein, alcohol intake and level of physical activity. The distributions for insulin, insulin sensitivity, IGFBP-1, -2, -3 and IAF were skewed and were $\log$ trans-formed before analysis. Data are presented as the mean $(95 \%$ confidence interval CI) at baseline and mean difference (95\% CI) of change between the WLG and the WSWGG at 6 and 12 months. Logged data (insulin, insulin sensitivity, IGFBP-1, $2,-3$ and IAF) are presented as geometric mean $(95 \% \mathrm{CI})$ at baseline and mean ratio $(95 \% \mathrm{CI})$ of change in logged values between groups at 6 and 12 months.

The relationship between the expanded panel of IGFrelated peptides and body fat compartments was examined by determining correlations between these values at baseline, and correlations between changes in body fat and IGF-I related peptides over 12 months. Spearman correlations were used for non parametric parameters.

\section{RESULTS}

Seventy four women were recruited to the study; five withdrew from the trial before 6 months and a further one before 12 months leaving hormone results for 69 women at 6 months and 68 at 12 months. Baseline characteristics for body size and composition of the WLG and WSWGG are shown in Table 1. Participants were mainly Caucasian, overweight/obese, and mainly sedentary with few undertaking recreational activity. There were no differences in adiposity or any of the IGF-related peptides between WLG and the WSWGG (Table 2). The WLG reported higher levels of moderate physical activity (housework and exercise) compared to the WSWGG at baseline $(\mathrm{P}<0.05$, Table 3$)$.
Changes in body size and the IGF-related peptides at 6 and 12 months are shown in Table 2. The WLG had significant reductions in body fat and visceral fat at 6 and 12 months compared to the WSWGG $(\mathrm{P}<0.001)$. The reductions in adiposity in the WLG occurred alongside significant improvements in insulin sensitivity (HOMA] and IGFBP-1 and 2 at 6 months (WLG vs. WSWGG, $\mathrm{P}<0.01$ ). The improvements in HOMA in the WLG as compared to the WSWGG were not sustained at 12 months $(\mathrm{P}=0.33)$ and accordingly, the increases in IGFBP-1 were attenuated in the WLG vs. the WSWGG at 12 months $(P=0.09)$. In the WLG, total IGF-I levels were numerically higher at 6 months as compared to the WSWGG (16 [-1.5 to 35$] \mu \mathrm{g} / 1, \mathrm{P}=0.07)$ and statistically higher at 12 months (17 [2.3 to 34$] \mu \mathrm{g} / 1, \mathrm{P}<0.01)$. WLG participants had significant increases in IGFBP-2 at both 6 $(\mathrm{P}<0.05)$ and 12 months $(\mathrm{P}<0.001)$. There were no significant differences in free IGF-I concentrations between the 2 groups at either $6(\mathrm{P}=0.49)$ or 12 months $(\mathrm{P}=0.21)$. Similarly IGFBP-3 did not differ between the 2 groups at $6(\mathrm{P}=0.97)$ or 12 months $(\mathrm{P}=0.99)$.

Changes in diet and exercise parameters over the year amongst women in the two groups are reported in Table 3. At 6 months, women in the WLG had a significant reductions in intakes of energy $(\mathrm{P}<0.01)$, fat and alcohol compared to the WSWGG group $(\mathrm{P}<0.05)$ but no significant increase in reported levels of physical activity $(\mathrm{P}=0.11)$. Only reductions in dietary fat were maintained at 12 months in the WLG compared to the WSWGG $(\mathrm{P}<0.01)$. Adjusting analyses of variance for the IGF axis amongst WLG and the WSWGG for energy, protein intake, activity level, and day of cycle did not change the results appreciably.

Correlations between adiposity, insulin sensitivity and IGF peptides at baseline are reported in Table 4. Both IGFBP-1 and -2 had negative correlations with weight, body fat, IAF and insulin sensitivity $(\mathrm{P}<0.001)$. Total IGF-I was negatively correlated to weight, body fat and IAF $(\mathrm{P}<0.05)$ whilst free IGF-I had a positive correlation with total IGF-I $(\mathrm{R}=0.648 ; \mathrm{P}<0.001)$.

Table 1. Baseline Characteristics of Study Participants

\begin{tabular}{|c|c|c|}
\hline & $\begin{array}{c}\text { Weight loss } \geq \mathbf{5 \%} \text { (WLG) } \\
\qquad(\mathrm{n}=\mathbf{2 6})\end{array}$ & $\begin{array}{c}\text { Weight loss }<5 \% \text { (WSGG) } \\
(\mathrm{n}=\mathbf{4 8})\end{array}$ \\
\hline Age (years) ${ }^{a}$ & $42.5 \pm 3.3$ & $40.3 \pm 2.7$ \\
\hline Ethnicity (\% Caucasian) & $92 \%$ & $94 \%$ \\
\hline Predicted lifetime risk of breast cancer $(\%)^{\mathrm{b}}$ & $22 \pm 6$ & $23 \pm 4$ \\
\hline Weight gain from age $20(\mathrm{~kg})^{\text {a }}$ & $19.9 \pm 11.3$ & $20.3 \pm 11.9$ \\
\hline$\%$ Body fat $(\mathrm{DXA})^{\mathrm{a}}$ & $39.0 \pm 6.4$ & $38.5 \pm 5.5$ \\
\hline Waist circumference $(\mathrm{cm})^{\mathrm{a}}$ & $99.3 \pm 15.4$ & $97.0 \pm 12.9$ \\
\hline Undertakes $>40$ minutes recreational activity / week (\%) & $10 \%$ & $10 \%$ \\
\hline
\end{tabular}

WLG (weight loss group) $=$ weight loss $\geq 5 \%$

WSWGG (weight stable / weight gain group) $=$ weight loss $<5 \%$ or weight gain

${ }^{a}$ Mean \pm SD

${ }^{\mathrm{b}}$ Determined from Tyrer Cuzick model (13) 
Table 2. Weight, Body Fat and IGF-1 Related Peptides at Baseline and Over One Year in Participants with $\geq 5 \%$ Weight Loss (WLG) and $<5 \%$ Weight Loss (WSWGG)

\begin{tabular}{|c|c|c|c|c|c|}
\hline & Baseline & $\begin{array}{l}\text { Mean difference of change } \\
\text { between groups at } 6 \text { months }\end{array}$ & P value ${ }^{3}$ & $\begin{array}{l}\text { Mean difference of change } \\
\text { between groups at } 12 \text { months }\end{array}$ & P value $^{3}$ \\
\hline $\begin{array}{c}\text { Weight }(\mathrm{kg})^{1} \\
\text { WLG } \\
\text { WSWGG }\end{array}$ & $\begin{array}{l}77.8(69.6 \text { to } 85.3) \\
78.0(73.9 \text { to } 82.6)\end{array}$ & $-7.4(-8.8$ to -6.1$)$ & $<0.001$ & $-6.1(-7.9$ to -4.3$)$ & $<0.001$ \\
\hline $\begin{array}{c}\text { Body fat }(\mathrm{kg})^{1} \\
\text { WLG } \\
\text { WSWGG }\end{array}$ & $\begin{array}{l}29.1(24.0 \text { to } 34.4) \\
29.3(26.6 \text { to } 32.0)\end{array}$ & $-5.4(-6.4$ to -4.4$)$ & $<0.001$ & $-5.1(-6.6$ to -3.6$)$ & $<0.001$ \\
\hline $\begin{array}{l}\text { IAF }\left(\mathrm{cm}^{2}\right)^{1} \\
\text { WLG } \\
\text { WSWGG }\end{array}$ & $\begin{array}{l}71.7(52.7 \text { to } 92.7) \\
78.7(66.6 \text { to } 93.1)\end{array}$ & $0.63(0.53$ to 0.71$)$ & $<0.005$ & $0.64(0.42$ to 0.71$)$ & $<0.005$ \\
\hline $\begin{array}{c}\text { Total IGF-1 }(\mu \mathrm{g} / \mathrm{l})^{1} \\
\text { WLG } \\
\text { WSWGG }\end{array}$ & $\begin{array}{l}149(130 \text { to } 169) \\
150(139 \text { to } 162)\end{array}$ & $16(-1.5$ to 35$)$ & 0.07 & 17 (2.3 to 34$)$ & 0.006 \\
\hline $\begin{array}{c}\text { Free IGF-1 }(\mu \mathrm{g} / \mathrm{l})^{1} \\
\text { WLG } \\
\text { WSWGG }\end{array}$ & $\begin{array}{l}1.4(1.2 \text { to } 1.6) \\
1.5(1.4 \text { to } 1.7)\end{array}$ & $0.1(-0.1$ to 0.3$)$ & 0.49 & $0.1(-0.1$ to 3.4$)$ & 0.21 \\
\hline $\begin{array}{c}\text { IGFBP-1 }(\mu \mathrm{g} / \mathrm{l})^{2} \\
\text { WLG } \\
\text { WSWGG }\end{array}$ & $\begin{array}{l}26.3 \text { (21.4 to } 32.9) \\
24.4 \text { (20.9 to } 28.6)\end{array}$ & 1.43 (1.14 to 1.69$)$ & 0.004 & $1.19(0.97$ to 1.45$)$ & 0.09 \\
\hline $\begin{array}{c}\text { IGFBP-2 }(\mu \mathrm{g} / \mathrm{l})^{2} \\
\text { WLG } \\
\text { WSWGG }\end{array}$ & $\begin{array}{l}188(153 \text { to } 231) \\
166(148 \text { to } 185)\end{array}$ & $1.22(1.04$ to 1.43$)$ & 0.04 & $1.24(1.06$ to 1.46$)$ & $<0.001$ \\
\hline $\begin{array}{c}\text { IGFBP-3 }\left(\mu \mathrm{g} / \mathrm{l}^{2}{ }^{2}\right. \\
\text { WLG } \\
\text { WSWGG }\end{array}$ & $\begin{array}{l}5022(4236 \text { to } 5440) \\
5280(5033 \text { to } 5539)\end{array}$ & $0.99(0.88$ to 1.11$)$ & 0.97 & $1.02(0.94$ to 1.20$)$ & 0.99 \\
\hline $\begin{array}{c}\text { IGF-1:IGFBP-3 ratio } \\
\text { WLG } \\
\text { WSWGG }\end{array}$ & $\begin{array}{l}0.029(0.025 \text { to } 0.033) \\
0.028(0.026 \text { to } 0.031)\end{array}$ & $0.004(-0.001$ to 0.008$)$ & 0.18 & $0.003(-0.001$ to 0.007$)$ & 0.005 \\
\hline $\begin{array}{c}\text { Insulin }(\mathrm{pmol} / \mathrm{l})^{2} \\
\text { WLG } \\
\text { WSWGG }\end{array}$ & $\begin{array}{l}39.6(31.0 \text { to } 51.0) \\
35.3(30.8 \text { to } 40.4)\end{array}$ & $0.67(0.53$ to 0.86$)$ & 0.006 & $0.86(0.63$ to 1.15$)$ & 0.33 \\
\hline $\begin{array}{c}\text { Insulin sensitivity } \\
(\mu \mathrm{U} / \mathrm{mmol} / \mathrm{l}) \\
\text { WLG } \\
\text { WSWGG }\end{array}$ & $\begin{array}{l}1.42(1.08 \text { to } 1.88) \\
1.26(1.09 \text { to } 1.45)\end{array}$ & $0.67(0.53$ to 0.86$)$ & 0.006 & $0.86(0.63$ to 1.15$)$ & 0.33 \\
\hline
\end{tabular}

WLG (weight loss group) = weight loss $\geq 5 \%$, WSWGG (weight stable / weight gain group) $=$ weight loss $<5 \%$ or weight gain

$\mathrm{IAF}=$ intra-abdominal fat

${ }^{1}$ Mean $(95 \% \mathrm{CI})$ for baseline values and mean $(95 \% \mathrm{CI})$ difference between WLG and WSWGG at 6 and 12 months.

${ }^{2}$ Geometric mean $(95 \% \mathrm{CI})$ for baseline values and mean $(95 \% \mathrm{CI})$ ratio of natural log values between WLG and WSWGG at 6 and 12 months.

${ }^{3} \mathrm{P}$ value for analysis of variance comparing women with $\geq 5 \%$ and $<5 \%$ weight loss adjusted for baseline value

${ }^{4}$ Insulin sensitivity (HOMA)

Baseline WLG $=26$, WLWGG $=48$

6 months $\mathrm{WLG}=23, \mathrm{WLWGG}=46$

12 months $\mathrm{WLG}=23, \mathrm{WLWGG}=45$ 
Table 3. Dietary Intake and Physical Activity at Baseline and Over One Year in Participants with $\geq 5 \%$ Weight Loss (WLG) and $<$ 5\% Weight Loss (WSWGG)

\begin{tabular}{|c|c|c|c|c|c|}
\hline & Baseline & $\begin{array}{l}\text { Mean difference of change } \\
\text { between groups at } 6 \text { months }\end{array}$ & P value $^{3}$ & $\begin{array}{l}\text { Mean difference of change } \\
\text { between groups at } 12 \text { months }\end{array}$ & P value ${ }^{3}$ \\
\hline $\begin{array}{l}\text { Energy }(\mathrm{kJ})^{1} \\
\quad \text { WLG } \\
\text { WSWGG }\end{array}$ & $\begin{array}{l}8929(7833 \text { to } 10,000) \\
8904(8184 \text { to } 9480)\end{array}$ & $-664(-1584$ to -247$)$ & $<0.01$ & $-530(-1592$ to 530$)$ & 0.21 \\
\hline $\begin{array}{l}\text { Protein }(g)^{1} \\
\quad \text { WLG } \\
\text { WSWGG }\end{array}$ & $\begin{array}{l}87(77 \text { to } 95) \\
85(80 \text { to } 91)\end{array}$ & $-0.2(-8.0$ to 8.0$)$ & 0.96 & $0.7(-9.0$ to 11.0$)$ & 0.90 \\
\hline $\begin{array}{c}\text { Saturated fat }(\mathrm{g})^{1} \\
\text { WLG } \\
\text { WSWGG } \\
\end{array}$ & $\begin{array}{l}28(22 \text { to } 33) \\
29(26 \text { to } 33)\end{array}$ & $-7.4(-12$ to -3$)$ & $<0.01$ & $-6(-12$ to -0.3$)$ & $<0.05$ \\
\hline $\begin{array}{l}\text { Alcohol }(\mathrm{g})^{1} \\
\text { WLG } \\
\text { WSWGG }\end{array}$ & $\begin{array}{l}11.0(4.9 \text { to } 16.4) \\
15.7(12.1 \text { to } 19.8)\end{array}$ & $-6.3(-12$ to -1.0$)$ & $<0.05$ & $-0.2(-6.3$ to 6.0$)$ & 0.97 \\
\hline $\begin{array}{l}\text { Fibre }(\mathrm{g})^{1} \\
\text { WLG } \\
\text { WSWGG }\end{array}$ & $\begin{array}{l}16.1(13.1 \text { to } 18.6) \\
14.3(13.2 \text { to } 16.3)\end{array}$ & $1.2(-0.5$ to 2.9$)$ & 0.27 & $0.3(-1.7$ to 2.3$)$ & 0.65 \\
\hline $\begin{array}{c}\text { Moderate activity (hours/week) }{ }^{2,4} \\
\text { WLG } \\
\text { WSWGG }\end{array}$ & $\begin{array}{l}3.9(2.3 \text { to } 5.0)^{5} \\
2.3(1.7 \text { to } 3.0)^{5}\end{array}$ & $1.53(0.91$ to 2.60$)$ & 0.11 & $1.42(0.84$ to 2.21$)$ & 0.20 \\
\hline $\begin{array}{c}\text { Distance walked (metres / } 6 \mathrm{~min})^{6} \\
\text { WLG } \\
\text { WSWGG }\end{array}$ & $\begin{array}{l}584(557 \text { to } 611) \\
570(552 \text { to } 588)\end{array}$ & $11.0(-9.0$ to 30.5$)$ & 0.28 & $22(-6$ to 51$)$ & 0.20 \\
\hline
\end{tabular}

WLG (weight loss group) = weight loss $\geq 5 \%$

WSWGG (weight stable / weight gain group) $=$ weight loss $<5 \%$ or weight gain

$\mathrm{IAF}=$ intra-abdominal fat

${ }^{1}$ Mean $(95 \% \mathrm{CI})$ for baseline values and mean $(95 \% \mathrm{CI})$ difference between WLG and WSWGG at 6 and 12 months.

${ }^{2}$ Geometric mean $(95 \% \mathrm{CI})$ for baseline values and mean $(95 \% \mathrm{CI})$ ratio of natural log values between WLG and WSWGG at 6 and 12 months.

${ }^{3} \mathrm{P}$ value for analysis of variance comparing women with $\geq 5 \%$ and $<5 \%$ weight loss adjusted for baseline value

${ }^{4}$ Self reported housework, walking and physical activity from physical activity questionnaire (26)

${ }^{5}$ Difference between baseline values for women with $\geq 5 \%$ and $<5 \%$ weight loss independent $t$ test $P$ value $<0.05$

${ }^{6}$ Standardised 6 minute walk test $(27)$

Baseline $W L G=26$, WLWGG $=48$

6 months WLG $=23$, WLWGG $=46$

12 months $\mathrm{WLG}=23, \mathrm{WLWGG}=45$

Table 4. Correlations between Adiposity Insulin Sensitivity and IGF-1 Related Peptides at Baseline (N=74)

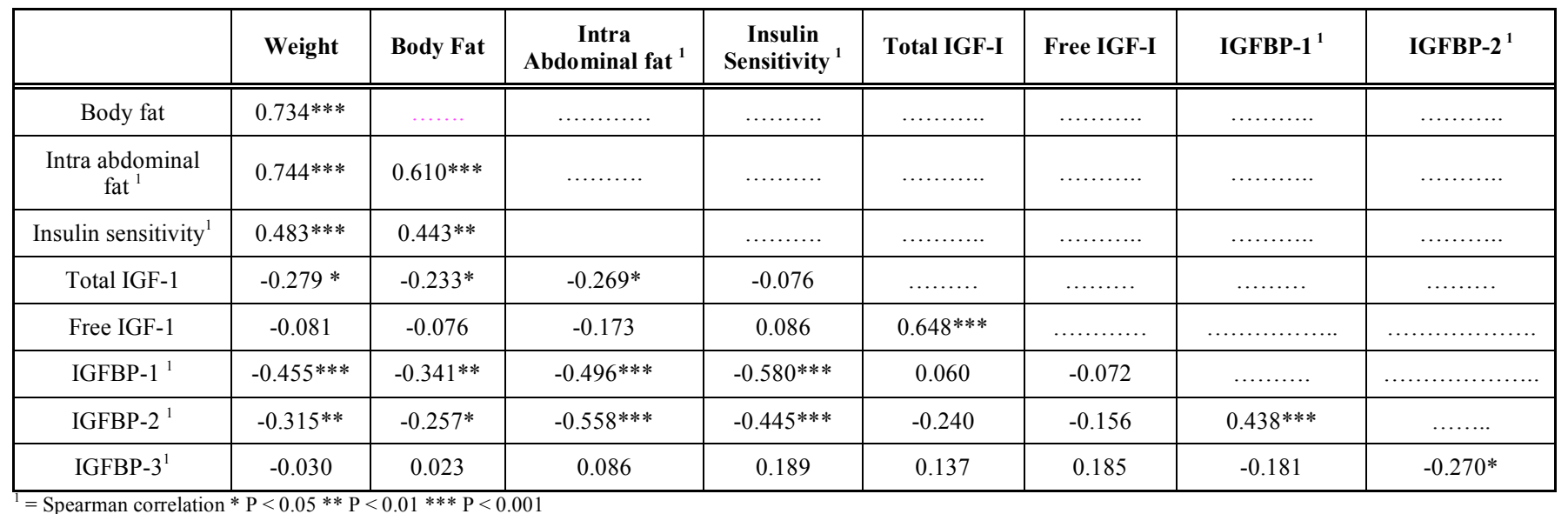

$=$ Spearman correlation $* \mathrm{P}<0.05 * * \mathrm{P}<0.01 * * * \mathrm{P}<0.001$ 
Changes in IGFBP-1 and -2 over 12 months were both negatively linked to changes in weight $(\mathrm{Rs}=-0.339$ and $0.315)$, body fat $(\mathrm{Rs}=-0.283$ and -0.346$)$ and $\operatorname{IAF}(\mathrm{Rs}=-0.343$ and -0.284) (all $\mathrm{P}<0.05)$. Change in IGFBP-1 was negatively linked to change in insulin sensitivity $\left(\mathrm{Rs}_{\mathrm{P}}=-0.406, \mathrm{P}<0.001\right)$. Change in total IGF-I was negatively linked to change in weight $(\mathrm{Rs}=-0.344)$, body fat $(\mathrm{R}=-0.321)$ and IAF $(\mathrm{Rs}=-$ 0.437) (all $\mathrm{P}<0.001$ ). Change in free IGF-I was linked negatively to change in IAF $\left(\mathrm{Rs}^{=-0.364)}\right.$ ) and positively to change in total IGF-I $(\mathrm{Rs}=0.424)($ both $\mathrm{P}<0.001)$.

\section{DISCUSSION}

\section{Main Findings}

This is one of the few prospective studies on the effects of weight loss on the IGF-axis which include measurement of free IGF-I using ultra-filtration. We have confirmed finding of previous weight loss studies by reporting increases in IGFBP-1 and -2, and improvements in insulin sensitivity with reduced adiposity. Weight loss was associated with increased circulating total IGF-I, and no significant change in serum concentrations of free IGF-I. Most likely, the failure to decrease free IGF-I with weight loss and associated increases in IGFBP-1 and -2 reflects the increased total IGFI levels with weight loss.

The increased total IGF-I with weight loss in our trial is consistent with a number of studies of modest weight loss amongst women [27] and men [28] and cross sectional data that mean IGF-I concentrations increase with BMI up to around $28 \mathrm{~kg} / \mathrm{m}^{2}$ and reduce as BMI increases further [29]. Increased total IGF-I most likely reflects improved insulin sensitivity alongside loss of IAF which in turn can directly stimulate hepatic IGF-I production [30] or increase IGF-I production via increased growth hormone secretion [31]. We did not however measure levels of growth hormone in the study.

Maintenance of free IGF-I in women with weight loss in the present study suggests any potential decrease in free IGFI levels associated with increased IGFBP-1 and IGFBP-2 is counterbalanced by the increase in total IGF-I. This contrasts with previous large cross-sectional studies which have positively linked free IGF-I (determined by ultra-filtration] with obesity [32] although this relationship does appear to be weaker amongst women than men [32] and is not present amongst insulin-resistant individuals with type 2 diabetes [33]. Our findings are however consistent with a recent small prospective study based on 13 male and 21 female obese non-diabetics (BMI $\sim 40 \mathrm{~kg} / \mathrm{m}^{2}$ ] which linked weight loss to increased total IGF-I, IGFBP-1 and -2 , but to no change in free IGF-I?? (ultra-filtration] [34]. A further study amongst 8 pre-menopausal obese women reported increases in dissociable (IRMA] and free IGF-I (ultra-filtration] alongside reductions in visceral fat and increased total IGFBP-1, -2 and total IGF-I [35].

Serum IGFBP-3 did not change in our study. High IGFBP-3 serum concentrations have been linked to breast cancer risk amongst both pre- and post-menopausal women [7] although not consistently. Previous reports have linked weight loss to an increase [36] or to no change in IGFBP-3 levels [11]. However, these and our measurements were based on the IRMA method which measures both intact and proteolysed forms of IGFBP-3. Proteolysis may be increased amongst heavier insulin-resistant subjects thus IRMA does not reflect the concentration of IGFBP-3 capable of sequestering IGFs in the bloodstream of these subjects.

\section{Strengths of Study}

The strength of our study is the inclusion of ultra-filtered free IGF-I, which may provide a more reliable estimate compared to IRMA/ELISA free IGF-I, which promotes dissociation of the IGF-I - IGFBP complex and accordingly overestimates unbound ligand. Following women over 12 months allowed us to assess the IGF axis during the active weight-losing phase (negative energy balance, 0 to 6 months] as well as during the weight maintenance phase (6 to 12 months). Energy restriction is linked to acute declines in total and free IGF-I amongst non-obese subjects, but not amongst obese subjects unless there is a concomitant reduction in protein intake ( $\leq 50 \mathrm{~g} /$ day) [37], which was not the case in our study. Increased IGFBP-1 and IGFBP-2 are associated with improvements in insulin sensitivity and consistent with the down regulation of hepatic IGFBP-1 production at the transcription level and IGFBP-2 at the translational level with chronic portal hyperinsulinaemia [26]. However the increases in IGFBP-1 and -2 in our cohort appeared to be maintained at 12 months in the absence of improved insulin sensitivity.

This is a small study; however our participants are a homogenous group of sedentary, non-smoking, pre-menopausal women with regular menstrual cycles. We did not include women with PCOS who are often heavier and are known to have higher levels of free IGF-I [38] which may confound some of the earlier observations of higher free IGF-I amongst heavier women. Women in the present study had a family history of breast cancer which in itself is unlikely to confound the overall results. Although around $50 \%$ of the inter-individual variability in circulating IGF-I and IGFBP-3 is known to be genetically determined [39], there is little convincing data of differences in the IGF-axis amongst women with and without a family history of breast cancer [13]. Women on this study were overweight or obese with no diagnosis of diabetes, although $75 \%$ of subjects had a degree of insulin resistance (HOMA $>1 \mu \mathrm{U} / \mathrm{mmol} / \mathrm{L}$ ).

\section{Study Limitations}

We have not examined the effects of a moderate energy restricted and exercise weight loss programme on the IGFaxis in the context of a randomised controlled trial due to the non-random method of group allocation. There were no differences in baseline levels of the IGF-related parameters between WLG and WSWGG women so lack of randomisation may not be important.

Changes in the IGF-axis with weight loss were achieved alongside decreased energy, fat and alcohol intake but no appreciable change in activity levels. It is unlikely that these specific changes in diet and exercise (rather than weight loss] have brought about the reported changes in IGF-I. Total IGF-I has a weak negative association with alcohol [21] but is mainly linked to protein intake which was maintained 
during the study [37]. There may be limitations in our self report assessment of physical activity. Not withstanding this, earlier reports have shown inconsistent effects of aerobic and strength training on the IGF-I axis amongst sedentary populations [40]. Fifty percent of studies in this review found no difference in total circulating IGF-I as a result of exercise, whilst $37 \%$ showed an increase, and $13 \%$ observed a decrease in IGF-I levels.

\section{IMPLICATIONS}

We have studied the effect of weight loss on the IGF-I axis in pre-menopausal women aged 35-45 years since observational studies indicate weight loss at this age to be particularly linked to reductions in risk of developing postmenopausal breast cancer $[3,41]$. The increase in total IGF-I and maintenance of free IGF-I alongside loss of total and intra-abdominal fat, improvements of insulin sensitivity and increased levels of IGFBP-1 and -2 suggest reductions in breast cancer risk with weight loss are unlikely to be mediated by the IGF-axis. The increased total IGF-I and IGFBP-1 associated with decline in visceral fat are however consistent with observational data linking higher levels of IGF-I to a lower risk of developing impaired glucose tolerance [42] and cardiovascular disease [43, 44]. There are few data to support the assumed relationship between free IGF-I and breast cancer risk. One study linked IRMAdetermined free IGF-I to risk [45], whilst another failed to link ELISA determined free IGF-I to risk [46]. Most prospective studies have failed to link IGFBP-1 and IGF-2 to breast risk [46-48, 49] with the exception of Greenback et al who reported IGFBP-2 to have an inverse relationship with breast cancer risk amongst post-menopausal women $[50,51]$.

\section{CONCLUSION}

In conclusion, moderate weight loss increases levels of total IGF-I but does not reduce levels of free IGF-I (measured by ultra-filtration) amongst obese pre-menopausal women. Our study does not inform the effects of weight loss on concentrations of locally produced IGF-I and binding proteins within the breast tissue itself which some believe may be more relevant to breast cancer risk [52]. Furthermore, it does not inform any potential synergistic effects of IGF-I with oestradiol or testosterone on breast cancer risk [53]. Future prospective randomised studies of diet and exercise weight loss interventions should examine bioactivity at tissue level possibly using the IGF kinase receptor activation (KIRA] assay [54] and ideally examining changes within the breast itself.

\section{CONTRIBUTORS}

Michelle Harvie, Allan Flyvbj-erg, Jack Cuzick and Anthony Howell initiated and designed the study. Michelle Harvie, Anthony Howell, Tom Mercer, Riz Malik and Judith Adams were responsible for patient recruitment, blood collection and measurement of body composition. The laboratory analyses were carried out under the supervision of Jan Frystyk and Allan Flyvbj-erg. Andrew Renehan under- took some analyses and advised on the interpretation. All investigators contributed to the writing of the paper.

\section{ACKNOWLEDGEMENTS}

We are indebted to the skilled technical assistance of Kirsten Nyborg, Susanne Sørensen and Karen Mathiassen in Aarhus, Denmark.

\section{GRANT SUPPORT}

This study was in part supported by Genesis Appeal and the Danish Medical Research Council. Andrew Renehan is a HEFCE-supported senior lecturer.

\section{POTENTIAL CONFLICTS OF INTEREST}

Andrew Renehan has received hospitality from Diagnostic Systems Laboratories and a lecture honorarium from Eli-Lilly. There are no conflicts of interest.

\section{REFERENCES}

[1] Renehan AG, Tyson M, Egger M, Heller RF, Zwahlen M. Bodymass index and incidence of cancer: a systematic review and metaanalysis of prospective observational studies. Lancet 2008; 371(9612): 569-78.

[2] Huang Z, Hankinson SE, Colditz GA, et al. Dual effects of weight and weight gain on breast cancer risk. JAMA 1997; 278(17): 140711.

[3] Harvie M, Howell A, Vierkant RA, et al. Association of gain and loss of weight before and after menopause with risk of postmenopausal breast cancer in the Iowa women's health study. Cancer Epidemiol Biomarkers Prev 2005; 14(3): 656-61.

[4] Eliassen AH, Colditz GA, Rosner B, Willett WC, Hankinson SE. Adult weight change and risk of postmenopausal breast cancer. JAMA 2006; 296(2): 193-201.

[5] Renehan AG, Frystyk J, Flyvbjerg A. Obesity and cancer risk: the role of the insulin-IGF axis. Trends Endocrinol Metab 2006; 17(8): 328-36.

[6] Renehan AG, Harvie M, Howell A. Insulin-like growth factor (IGF)-I, IGF binding protein-3, and breast cancer risk: eight years on. Endocr Relat Cancer 2006; 13(2): 273-8.

[7] Rinaldi S, Peeters PH, Berrino F, et al. IGF-I, IGFBP-3 and breast cancer risk in women: The European Prospective Investigation into Cancer and Nutrition (EPIC). Endocr Relat Cancer 2006; 13(2): 593-05.

[8] Lee PD, Giudice LC, Conover CA, Powell DR. Insulin-like growth factor binding protein-1: recent findings and new directions. Proc Soc Exp Biol Med 1997; 216(3): 319-57.

[9] Hellenius ML, Brismar KE, Berglund BH, de Faire UH. Effects on glucose tolerance, insulin secretion, insulin-like growth factor 1 and its binding protein, IGFBP-1, in a randomized controlled diet and exercise study in healthy, middle-aged men. J Intern Med 1995; 238(2): 121-30.

[10] Butzow TL, Lehtovirta M, Siegberg R, et al. The decrease in luteinizing hormone secretion in response to weight reduction is inversely related to the severity of insulin resistance in overweight women. J Clin Endocrinol Metab 2000; 85(9): 3271-75.

[11] Kaaks R, Bellati C, Venturelli E, et al. Effects of dietary intervention on IGF-I and IGF-binding proteins, and related alterations in sex steroid metabolism: the Diet and Androgens (DIANA] Randomised Trial. Eur J Clin Nutr 2003; 57(9): 1079-88.

[12] Gomez JM, Maravall FJ, Gomez N, Navarro MA, Casamitjana R, Soler J. The IGF-I system component concentrations that decrease with ageing are lower in obesity in relationship to body mass index and body fat. Growth Horm IGF Res 2004; 14(2): 91-6. 
[13] Amir E, Evans DG, Shenton A, et al. Evaluation of breast cancer risk assessment packages in the family history evaluation and screening programme. J Med Genet 2003; 40(11): 807-14.

[14] Azziz R, Carmina E, Dewailly D, et al. Positions statement: criteria for defining polycystic ovary syndrome as a predominantly hyperandrogenic syndrome: an Androgen Excess Society guideline. J Clin Endocrinol Metab 2006; 91(11): 4237-45.

[15] Schofield WN. Predicting basal metabolic rate, new standards and review of previous work. Hum Nutr Clin Nutr 1985; 39 (Suppl 1): $5-41$.

[16] Jakicic JM, Clark K, Coleman E, et al. American College of Sports Medicine position stand. appropriate intervention strategies for weight loss and prevention of weight regain for adults. Med Sci Sports Exerc 2001; 33(12): 2145-56.

[17] World Cancer Research Fund. Diet and health recommendations for the prevention of cancer. London 2002.

[18] Sallis JF, Haskell WL, Wood PD, et al. Physical activity assessment methodology in the Five-City Project. Am J Epidemiol 1985; 121(1): 91-06.

[19] White RD, Evans CH. Performing the exercise test. Prim Care 2001; 28(1): 29-53.

[20] Seiddell J. Waist / hip and waist / thigh ratios. Nutritioal status assessment: a manual for population studies. In: Fidanza, Ed. London: Chapman and Hall 1991; pp. 24-29.

[21] Lavigne JA, Wimbrow $\mathrm{HH}$, Clevidence BA, et al. Effects of alcohol and menstrual cycle on insulin-like growth factor-I and insulin-like growth factor binding protein-3. Cancer Epidemiol Biomarkers Prev 2004; 13(12): 2264-7.

[22] Frystyk J, Flyvbjerg A. Measurement of insulin like growth factor bioactivity in humans. the expanding role of octeotride. In: Lamberts SWJ, Ghigo E, Eds. Advances in endocrinology and eye diseases. Bristol: Bioscienrifica Ltd. 2002; pp. 225-33.

[23] Frystyk J, Dinesen B, Orskov H. Non-competitive time-resolved immunofluorometric assays for determination of human insulinlike growth factor I and II. Growth Regul 1995; 5(4): 169-76.

[24] Krassas GE, Pontikides N, Kaltsas T, et al. Free and total insulinlike growth factor (IGF)-I, -II, and IGF binding protein-1, -2, and 3 serum levels in patients with active thyroid eye disease. $\mathrm{J}$ Clin Endocrinol Metab 2003; 88(1): 132-5.

[25] Matthews DR, Hosker JP, Rudenski AS, Naylor BA, Treacher DF, Turner RC. Homeostasis model assessment: insulin resistance and beta-cell function from fasting plasma glucose and insulin concentrations in man. Diabetologia 1985; 28(7): 412-19.

[26] Frystyk J. Free insulin-like growth factors -- measurements and relationships to growth hormone secretion and glucose homeostasis. Growth Horm IGF Res 2004; 14(5): 337-75.

[27] Poulos JE, Leggett-Frazier N, Khazanie P, et al. Circulating insulin-like growth factor I concentrations in clinically severe obese patients with and without NIDDM in response to weight loss. Horm Metab Res 1994; 26(10): 478-80.

[28] Kunitomi M, Wada J, Takahashi K, et al. Relationship between reduced serum IGF-I levels and accumulation of visceral fat in Japanese men. Int J Obes Relat Metab Disord 2002; 26(3): 361-9.

[29] Lukanova A, Toniolo P, Akhmedkhanov A, et al. A cross-sectional study of IGF-I determinants in women. Eur J Cancer Prev 2001; 10(5): 443-52.

[30] Boni-Schnetzler M, Schmid C, Meier PJ, Froesch ER. Insulin regulates insulin-like growth factor I mRNA in rat hepatocytes. Am J Physiol 1991; 260(6 Pt 1): E846-51.

[31] Clasey JL, Weltman A, Patrie J, et al. Abdominal visceral fat and fasting insulin are important predictors of 24-hour GH release independent of age, gender, and other physiological factors. J Clin Endocrinol Metab 2001; 86(8): 3845-52.

[32] Frystyk J, Vestbo E, Skjaerbaek C, Mogensen CE, Orskov H. Free insulin-like growth factors in human obesity. Metabolism 1995; 44(10 Suppl 4): 37-44.

[33] Frystyk J, Skjaerbaek C, Vestbo E, Fisker S, Orskov H. Circulating levels of free insulin-like growth factors in obese subjects: the impact of type 2 diabetes. Diabetes Metab Res Rev 1999; 15(5): 314-22.
[34] Espelund U, Bruun JM, Richelsen B, Flyvbjerg A, Frystyk J. Proand mature IGF-II during diet-induced weight loss in obese subjects. Eur J Endocrinol 2005; 153(6): 861-9.

[35] Rasmussen MH, Juul A, Hilsted J. Effect of weight loss on free insulin-like growth factor-I in obese women with hyposomatotropism. Obesity 2007; 15(4): 879-86.

[36] Rasmussen MH, Hvidberg A, Juul A, et al. Massive weight loss restores 24-hour growth hormone release profiles and serum insulin-like growth factor-I levels in obese subjects. J Clin Endocrinol Metab 1995; 80(4): 1407-15.

[37] Musey VC, Goldstein S, Farmer PK, Moore PB, Phillips LS Differential regulation of IGF-1 and IGF-binding protein-1 by dietary composition in humans. Am J Med Sci 1993; 305(3): 131-8.

[38] Thierry van Dessel HJ, Lee PD, Faessen G, Fauser BC, Giudice LC. Elevated serum levels of free insulin-like growth factor I in polycystic ovary syndrome. J Clin Endocrinol Metab 1999; 84(9): 3030-5.

[39] Harrela M, Koistinen H, Kaprio J, et al. Genetic and environmental components of interindividual variation in circulating levels of IGF-I, IGF-II, IGFBP-1, and IGFBP-3. J Clin Invest 1996; 98(11): 2612-15.

[40] Orenstein MR, Freidenerich C. Review of physical activity and the IGF family. J Phys Act Health 2004; 1, 291-320.

[41] Radimer KL, Ballard-Barbash R, Miller JS, et al. Weight change and the risk of late-onset breast cancer in the original framingham cohort. Nutr Cancer 2004; 49(1): 7-13.

[42] Sandhu MS, Heald AH, Gibson JM, Cruickshank JK, Dunger DB, Wareham NJ. Circulating concentrations of insulin-like growth factor-I and development of glucose intolerance: a prospective observational study. Lancet 2002; 359(9319): 1740-5.

[43] Murgatroyd PR, Fruhbeck G, Goldberg GR, et al. Leptin does not respond to $48 \mathrm{~h}$ fat deposition or mobilization in women. Int J Obes Relat Metab Disord 2003; 27(4): 457-62.

[44] Juul A, Scheike T, Davidsen M, Gyllenborg J, Jorgensen T. Low serum insulin-like growth factor I is associated with increased risk of ischemic heart disease: a population-based case-control study. Circulation 2002; 106(8): 939-44.

[45] Li BD, Khosravi MJ, Berkel HJ, et al. Free insulin-like growth factor-I and breast cancer risk. Int J Cancer 2001; 91(5): 736-9.

[46] Schernhammer ES, Holly JM, Pollak MN, Hankinson SE. Circulating levels of insulin-like growth factors, their binding proteins, and breast cancer risk. Cancer Epidemiol Biomarkers Prev 2005; 14(3): 699-04.

[47] Keinan-Boker L, Bueno De Mesquita HB, Kaaks R, et al. Circulating levels of insulin-like growth factor I, its binding proteins $-1,-2,-3$, C-peptide and risk of postmenopausal breast cancer. Int J Cancer 2003; 106(1): 90-5.

[48] Kaaks R, Lundin E, Rinaldi S, et al. Prospective study of IGF-I, IGF-binding proteins, and breast cancer risk, in northern and southern Sweden. Cancer Causes Control 2002; 13(4): 307-16.

[49] Krajcik RA, Borofsky ND, Massardo S, Orentreich N. Insulin-like growth factor I (IGF-I), IGF-binding proteins, and breast cancer. Cancer Epidemiol Biomarkers Prev 2002; 11(12): 1566-73.

[50] Verloop J, Rookus MA, van der KK, van Leeuwen FE. Physical activity and breast cancer risk in women aged 20-54 years. J Natl Cancer Inst 2000; 92(2): 128-35.

[51] Gronbaek H, Flyvbjerg A, Mellemkjaer L, et al. Serum insulin-like growth factors, insulin-like growth factor binding proteins, and breast cancer risk in postmenopausal women. Cancer Epidemiol Biomarkers Prev 2004; 13(11 Pt 1): 1759-64.

[52] Perks CM, Holly JM. IGF binding proteins (IGFBPs] and regulation of breast cancer biology. J Mammary Gland Biol Neoplasia 2008; 13(4): 455-69.

[53] Yu H, Shu XO, Li BD, et al. Joint effect of insulin-like growth factors and sex steroids on breast cancer risk. Cancer Epidemiol Biomarkers Prev 2003; 12(10): 1067-73.

[54] Chen JW, Ledet T, Orskov H, et al. A highly sensitive and specific assay for determination of IGF-I bioactivity in human serum. Am J Physiol Endocrinol Metab 2003; 284(6): E1149-55. 